\title{
Durability of ultra-high performance fibered concretes made from local raw materials in two aggressive media of hydrochloric acid and barium sulphates
}

Durabilitatea betoanelor fibrate de înaltă performanță obținute din materii prime locale în două medii agresive de acid clorhidric și sulfați de bariu

\author{
Farida Ait Medjber ${ }^{1,2}$, Mohammed Saidi² \\ ${ }^{1}$ University Mouloud Mammeri \\ 15000 Tizi-Ouzou, Algeria. \\ E-mail:farida.pcmc@gmail.com \\ ${ }^{2}$ Research Unit: Materials, Processes and Environment (RU-MPE), University M'hamed Bougara \\ 35000 Boumerdes, Algeria.
}

\begin{abstract}
The durability of ultra high performance fiber-reinforced concrete (UHPFC) made from local raw materials has been studied in this manuscript. An experimental study was carried out on the best variants of UHPFC using finely ground dune sand as ultrafine. The UHPFCs studied were developed from Portland cement $(P C)$, dune sand $(D S)$, fine sand $(F S)$, metal fibers $(M F)$ and superplasticizer additive (SP). The results show that it is possible to manufacture a more ductile and durable fiber concrete of 41.96 and 35.28 MPa for flexural tensile and 95.5 and 85.36 MPa for compressive strength for UHPFCs made from dune sand and immersed respectively in two chemical solutions concentrated at 5M hydrochloric acid and barium sulfate for one year. The manufacture of a concrete based on local raw materials with good mechanical properties and durability can reduce the consumption of cement.
\end{abstract}

Key words: Dune sand, ultra fine, ultra high performance fiber-reinforced concrete (UHPFC), durability, mechanical properties.

\section{Introduction}

The durability of concrete structures is a very important feature, as it guarantees increased safety and service life of these structures [1]. This durability also guarantees considerable savings in the long term, as such structures will require little or no repair, resulting in cost savings from repairs, which can be very high and may even exceed initial construction costs [2]. The development of such works must necessarily involve mastering and understanding the factors affecting their sustainability [3]. 
Farida Ait Medjber, Mohammed Saidi

Free water can penetrate the network of pores and capillaries in concrete and bring with it aggressive ions that can react with the hydrates and change their structure. A durable concrete is a concrete that resists the penetration of aggressive agents and allows a significant life span for concrete structures [4].

External aggressions such as chlorides, $\mathrm{CO}_{2}$ and chemical attacks can degrade the physical and mechanical properties of concrete and its durability over time. Among chemical attacks, acids that can come from both industrial areas and urban activity most severely degrade concrete [5].

\section{Content of the paper}

\section{Materials and experimental method}

\subsection{Used materials}

Cement (CP): the cement used is of the CEMI 52.5 type, with a density of $3160 \mathrm{~kg} / \mathrm{m} 3$ and a Blaine surface area of $4800 \mathrm{~cm} 2 / \mathrm{g}$. The physical, chemical and mineralogical characteristics are given in Table 1, and are in accordance with standard NF EN 197-1 standard [6-7].

Sand of dune (SD): in this work, finely ground dune sand up to a fineness of 4000 $\mathrm{cm} 2 / \mathrm{g}$ is used as a substitute in cement on the one hand and as fines added in the concrete formulation on the other.

Fine sand (FS): For the sand, it was opted for quarry sand from the Bouzegza region sieved on a $2 \mathrm{~mm}$ screen and $76 \%$ sand equivalent, and sand expansion of $23.3 \%$.

Superplasticizer (SP): In order to reduce the E/L ratio and increase the fluidity of the concretes for ease of application while maintaining a level of performance, a Tempo 12 high water-reducing superplasticizer from sika was used in accordance with EN 934-2 [7].

Metal fibers (MF): The metal fibers are then added to provide better strength and ductile behavior in concrete. 
Durability of ultra-high performance fibered concretes made from local raw materials in two aggressive media of hydrochloric acid and barium sulphates

Table 1

Characteristics of cementitious materials

\begin{tabular}{ccc}
\hline Minerals & CEM I 52.5 (PC) & Sand of dune (SD) \\
\hline$\% \mathrm{SiO}_{2}$ & 20.03 & 94.40 \\
$\% \mathrm{Al}_{2} \mathrm{O}_{3}$ & 5.07 & 2.23 \\
$\% \mathrm{Fe}_{2} \mathrm{O}_{3}$ & 3.43 & 0.33 \\
$\% \mathrm{CaO}$ & 62.43 & 0.45 \\
$\% \mathrm{MgO}$ & 1.64 & 0.06 \\
$\% \mathrm{SO}_{3}$ & 2.57 & 0.17 \\
$\% \mathrm{~K}_{2} \mathrm{O}$ & 0.59 & 1.13 \\
$\% \mathrm{Na}_{2} \mathrm{O}$ & 0.04 & 0.36 \\
$\% \mathrm{P}_{2} \mathrm{O}_{5}$ & 0.15 & 0.01 \\
$\% \mathrm{TiO}_{2}$ & 0.21 & 0.04 \\
$\% \mathrm{P}_{\mathrm{A} . \mathrm{F}}$ & 3.81 & 0.82 \\
$\% \mathrm{C}_{3} \mathrm{~S}$ & 62.89 & - \\
$\% \mathrm{C}_{2} \mathrm{~S}$ & 10.33 & - \\
$\% \mathrm{C}_{3} \mathrm{~A}$ & 7.64 & - \\
$\% \mathrm{C}_{4} \mathrm{AF}$ & 10.43 & - \\
Specific mass $\left(\mathrm{g} / \mathrm{cm}^{3}\right)$ & 2.93 & 2.95 \\
Specific surface $\left(\mathrm{cm}^{2} / \mathrm{g}\right)$ & 4800 & 4000 \\
\hline
\end{tabular}

Table 2

Characteristics of the adjuvant

\begin{tabular}{cc}
\hline Characteristics & The adjuvant of SIKA \\
\hline Aspect & Light brown liquid \\
$\mathrm{Na}_{2} \mathrm{O}$ content Eq & $\leq 1 \%$ \\
PH & $6 \pm 1$ \\
Density & $1.06 \pm 0.01$ \\
Dry extract & $30.2 \pm 1.3 \%$ \\
Conditioning & $230 \mathrm{Kg}$ drums \\
& $\mathrm{CP}$ of $1000 \mathrm{~L}$ \\
& bulk \\
\hline
\end{tabular}

\subsection{Working methodology}

This study was carried out in three parts. First of all, the work consists in studying the effect of the sand of finely ground dunes $(5,10,15$ and $20 \%$ by mass) by replacing cement on the rheological behavior of the cement pastes used for the different concretes studied. In this case, the amount of superplasticizer has been optimized to ensure adequate fluidity and avoid segregation. The second part was carried out on ultra high performance concretes with an optimal percentage of dune sand substituted in the cement by measuring the mechanical strength at 2, 7 and 28 days. Then, the optimization of the BFUHP with 2, 3.5 and 5\% metal fibers of the two variants BUHP1 and BUHP2 by measuring the mechanical resistance also at 2, 7 and 28 days. 
Afterwards, the optimization of the substitution percentage and the fiber percentage optimization, the best variant was determined with the best mechanical properties at 28 days. Finally, the third part was devoted to studying the durability of the best variant specimens in two chemical media of $5 \mathrm{M}$ concentration for a period of one year.

\subsection{Test methods}

Rheological tests: Using a VT550 type viscometer with coaxial cylindrical geometry, rheological tests were carried out. The measurements were carried out according to the following protocol (first of all: Pre-shear and ramp the shear rate to $350 \mathrm{~s}^{-1}$ for $60 \mathrm{~s}$. Second step: maintain a constant shear rate at $350 \mathrm{~s}^{-1}$ for 300 seconds). All of the cementitious pastes tested were prepared with a fixed dosage of superplasticizer and a ratio of $\mathrm{W} / \mathrm{C}=0.29 \mathrm{kept}$ constant [8].
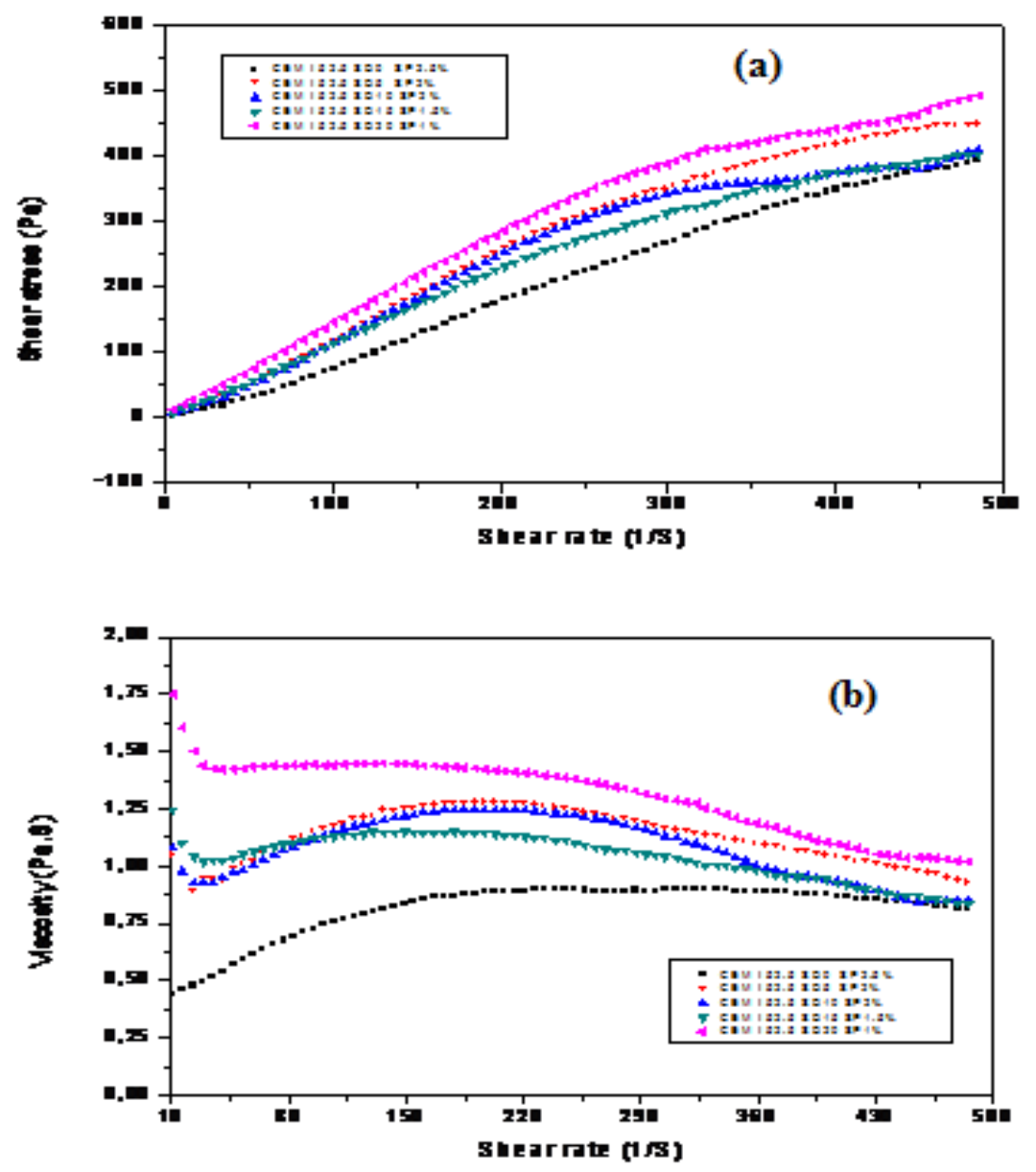

Fig. 1. Variation of shear stress (a) and plastic viscosity (b) as a function of shear rate 
Durability of ultra-high performance fibered concretes made from local raw materials in two aggressive media of hydrochloric acid and barium sulphates

Mechanical tests: The specimens were made according to standard NF EN 196-1[9], cast in prismatic moulds $(4 \times 4 \times 16 \mathrm{~cm} 3)$ then unmoulded after 24 hours and stored in a water bath until the days of mechanical crushing. The compressive and bending strengths of the specimens were tested at 2, 7 and 28 days using a $200 \mathrm{KN}$ computercontrolled "IBERTEST" type apparatus. The three-point bending tests were performed on prismatic samples according to ASTM C348 [10]. The half-samples were subjected to compressive stress in accordance with ASTM C349 [11].

\section{Results and discussion}

\subsection{Rheological study}

Figures $1 \mathrm{a}$ and $1 \mathrm{~b}$ show the variation in shear stress and viscosity of cement paste at different substitution rates by finely ground dune sand as a function of shear rate. It is clearly observed that the higher the doses of superplasticizer, the more fluid the cementitious pastes become [12-14]. This fluidity facilitates the formulation of ultrahigh performance concretes, particularly in the presence of fibers [15].

Analysis of the experimental curves shows that the appearance of the curves remains broadly identical for all sand concentrations in the dunes. There is an increase in viscosity as the sand concentration of the dunes increases.

\subsection{Effect of dune sand on the mechanical performance of UHPCs}

Ultra high performance concretes (UHPC) with different percentages of finely ground dune sand (SDS) as a substitute in cement have been developed. Table 3 illustrates the different concrete compositions studied. Then, and in order to determine an optimal percentage of SD, the mechanical resistances were measured at 2, 7 and 28 days and the results obtained are given in Table 4.

Table 3

Different compositions of ultra high performance concretes (UHPC)

\begin{tabular}{cccccc}
\hline Components & UHPC0 & UHPC1 & UHPC2 & UHPC3 & UHPC4 \\
\hline PC $[\mathrm{Kg}]$ & 1000 & 950 & 900 & 850 & 800 \\
SD $[\mathrm{Kg}]$ & 148.8 & 148.8 & 148.8 & 148.8 & 148.8 \\
SDS $[\mathrm{Kg}]$ & 0 & 50 & 100 & 150 & 200 \\
FS $[\mathrm{Kg}]$ & 958 & 958 & 958 & 958 & 958 \\
SP $[\mathrm{Kg}]$ & 24.8 & 20.3 & 20.3 & 15 & 10 \\
Water [Kg] & 246.7 & 250.9 & 251.6 & 255.3 & 258.6 \\
W/B & 0.23 & 0.23 & 0.23 & 0.23 & 0.23 \\
\hline
\end{tabular}


Farida Ait Medjber, Mohammed Saidi

Mechanical Resistance of UHPC with SD Rate

\begin{tabular}{ccccccc}
\hline & \multicolumn{3}{c}{ Flexural strength $(\mathrm{MPa})$} & \multicolumn{3}{c}{ Compressive strength (MPa) } \\
\cline { 2 - 7 } & $02 \mathrm{D}$ & $07 \mathrm{D}$ & $28 \mathrm{D}$ & $02 \mathrm{D}$ & $07 \mathrm{D}$ & $28 \mathrm{D}$ \\
\hline UHPC0 & 8.02 & 10.14 & 11.23 & 39.07 & 54.20 & 70.66 \\
UHPC1 & 13.27 & 14.31 & 15.62 & 71.76 & 93.64 & 103 \\
UHPC2 & 12.07 & 13.5 & 14.59 & 70.21 & 90.55 & 99.6 \\
UHPC3 & 13.53 & 14.78 & 15.11 & 68.94 & 89.2 & 96.32 \\
UHPC4 & 12.93 & 14.47 & 14.9 & 68.87 & 87.73 & 96.98 \\
\hline
\end{tabular}

According to Table 4, dune sand has a beneficial effect on mechanical performance and shows a significant improvement in the bending and compressive strength of the concretes studied compared to the UHPC0 control concrete. This is because the addition of finely ground dune sand affects the hydration reactions by pozzolanic reaction of well-dispersed cement grains with portlandite $\left(\left(\mathrm{Ca}(\mathrm{OH})_{2}\right)\right.$, thus modifying their growth rate and morphology [16-20].

Due to their manoeuvrability, fibers are only added to the first two variants UHPC1 and UHPC2; UHPC3 and UHPC4 cannot accept the fibers they are firm.

\subsection{Effect of dune sand on the mechanical performance of UHPFCs}

In this section, and in order to assess the influence of dune sand as a mineral addition, concrete formulations were drawn from the previous section of the study. Metal fibers were selected and used at different contents in the binder mass fraction $(2,3.5$ and $5 \%)$ as reinforcing fibers. Metal fibers were therefore added to ultra-high performance dune sand concrete to improve the ductility of the material, both in tension and compression [20-24]. The formulation of the UHPCs is given in Table 5.

Table 5

Formulation of BFUHP Ultra High Performance Fiber Concrete in $1 \mathrm{~m}^{\mathbf{3}}$

\begin{tabular}{|c|c|c|c|}
\hline \multicolumn{2}{|c|}{ Components } & UHPFC1 & UHPFC2 \\
\hline \multicolumn{2}{|c|}{$\mathrm{PC}[\mathrm{Kg}]$} & 950 & 900 \\
\hline \multicolumn{2}{|l|}{$\mathrm{SD}[\mathrm{Kg}]$} & 148.8 & 148.8 \\
\hline \multicolumn{2}{|c|}{ SDS $[\mathrm{Kg}]$} & 50 & 100 \\
\hline \multicolumn{2}{|l|}{ FS $[\mathrm{Kg}]$} & 958 & 958 \\
\hline \multirow[t]{3}{*}{$\mathrm{MF}[\mathrm{Kg}]$} & $2 \%$ & 20 & 20 \\
\hline & $3.5 \%$ & 35 & 35 \\
\hline & $5 \%$ & 50 & 50 \\
\hline \multicolumn{2}{|l|}{$\mathrm{SP}[\mathrm{Kg}]$} & 20.3 & 20.3 \\
\hline \multicolumn{2}{|c|}{ Water $[\mathrm{Kg}]$} & 250.9 & 251.6 \\
\hline \multicolumn{2}{|l|}{$\mathrm{W} / \mathrm{B}$} & 0.23 & 0.23 \\
\hline
\end{tabular}


Durability of ultra-high performance fibered concretes made from local raw materials in two aggressive media of hydrochloric acid and barium sulphates

Mechanical performance was assessed by measuring compressive and bending strength at different ages (2, 7 and 28 days) and the results obtained are shown in Table 6.

Table 6

Mechanical Resistance of BFUHP with Fiber Rate

\begin{tabular}{|c|c|c|c|c|c|c|c|}
\hline & \multirow[b]{2}{*}{$\operatorname{MF}(\%)$} & \multicolumn{3}{|c|}{ Flexural strength (MPa) } & \multicolumn{3}{|c|}{ Compressive strength (MPa) } \\
\hline \multirow{4}{*}{$\begin{array}{l}\bar{U} \\
\text { S } \\
\end{array}$} & & $02 \mathrm{D}$ & $07 \mathrm{D}$ & $28 \mathrm{D}$ & $02 \mathrm{D}$ & $07 \mathrm{D}$ & $28 \mathrm{D}$ \\
\hline & 2 & 14.12 & 20.63 & 22.23 & 75.15 & 97.18 & 113.63 \\
\hline & 3.5 & 13.88 & 25.66 & 30.27 & 77.23 & 105.38 & 125.15 \\
\hline & 5 & 15.47 & 26.63 & 33.9 & 77.54 & 103.32 & 134.43 \\
\hline \multirow{3}{*}{ 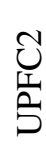 } & 2 & 14.83 & 23.16 & 30.1 & 78.2 & 95.65 & 120.55 \\
\hline & 3.5 & 14.80 & 25.68 & 32.53 & 77.21 & 99.75 & 126.23 \\
\hline & 5 & 16.48 & 30.2 & 34.08 & 85.25 & 102.97 & 135.33 \\
\hline
\end{tabular}
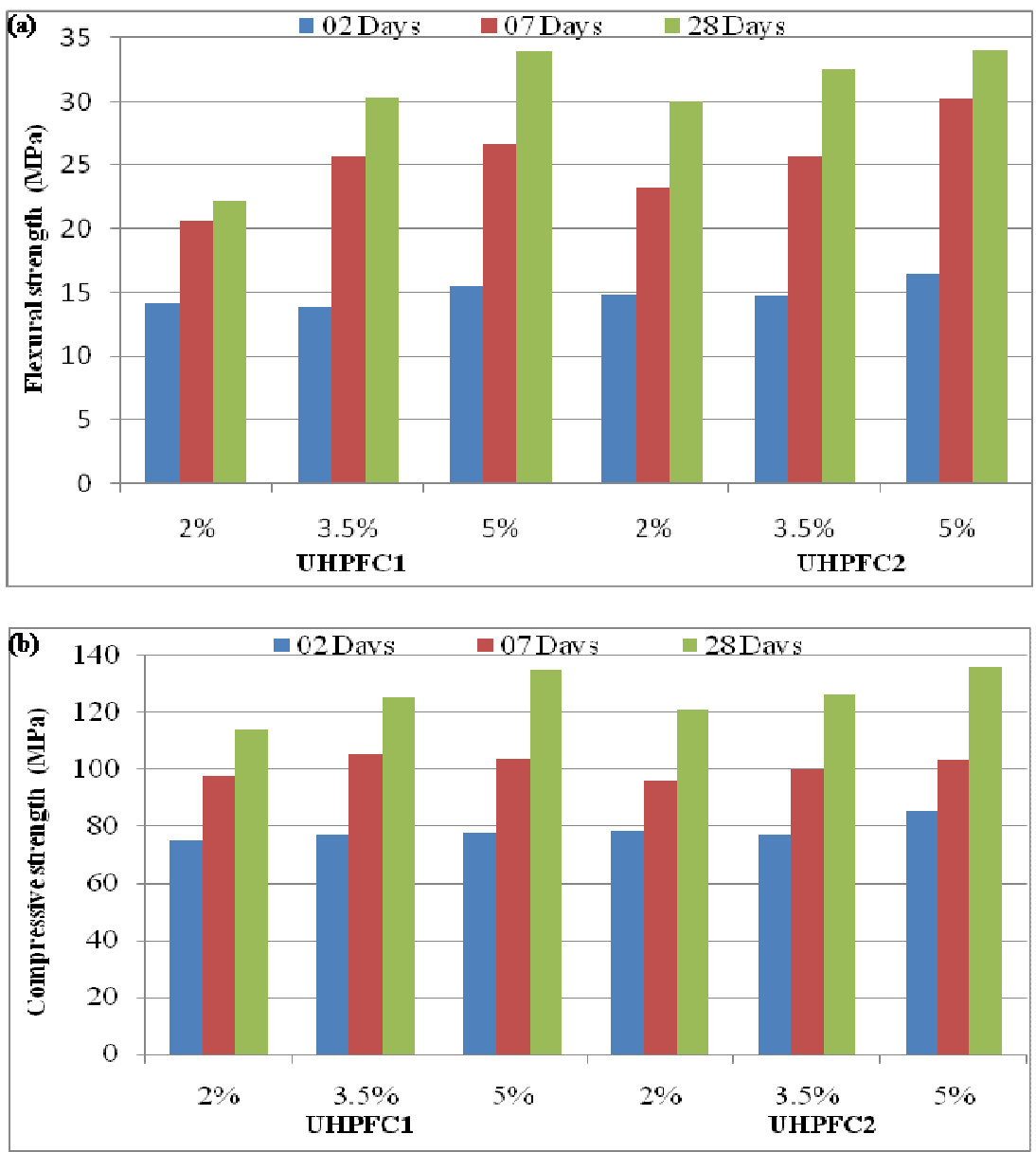

Fig. 2. Evolution of flexural (a) and compressive (b) strengths of UHPFC1 and UHPFC2 with fiber content and age 
Figures $2 \mathrm{a}$ and $2 \mathrm{~b}$ show the evolution of mechanical strength with age and fiber content. Resistance increases from 02 to 07 up to 28 days for each of the two variants BFUHP1 and BFUHP2, and the latter has higher values than UHPFC1 at 28 days for a percentage of $5 \%$ fiber. So the best variant is the one that substitutes $10 \%$ of the cement for the sand of the finely ground dunes with a 5\% fiber content called BFUHP2 with $5 \%$ fibers.

\subsection{Durability of UHPFC specimens}

All specimens were made according to the same procedure followed in the previous section and were stored in a water bath at $20^{\circ} \mathrm{C} \pm 2^{\circ} \mathrm{C}$. After maturation, the specimens were removed from the water bath, air-dried and steamed at $105^{\circ} \mathrm{C}$ for 24 hours to constant masses. Two 5M solutions of hydrochloric acid $(\mathrm{HCl})$ and barium sulphates (BaSO4) were prepared at PHs of 01 and 05 respectively. Then three specimens were immersed in each solution, and three others were left out in the open as a control. The chemical attack was followed in both media for one year and the solutions were repeated at the same $\mathrm{PH}$ after six months.

\subsubsection{The loss of mass}

The chemical resistance was evaluated according to ASTM C 267-96 [25] by measuring the mass loss of the specimen calculated by the following formula:

Mass variation $(\%)=\frac{M_{3}-M_{2}}{M_{1}} \times 100$

With $\mathrm{M}_{1}, \mathrm{M}_{2}$ the masses of the specimens before and after immersion, respectively. This operation was performed after 6 and 12 months of immersion.

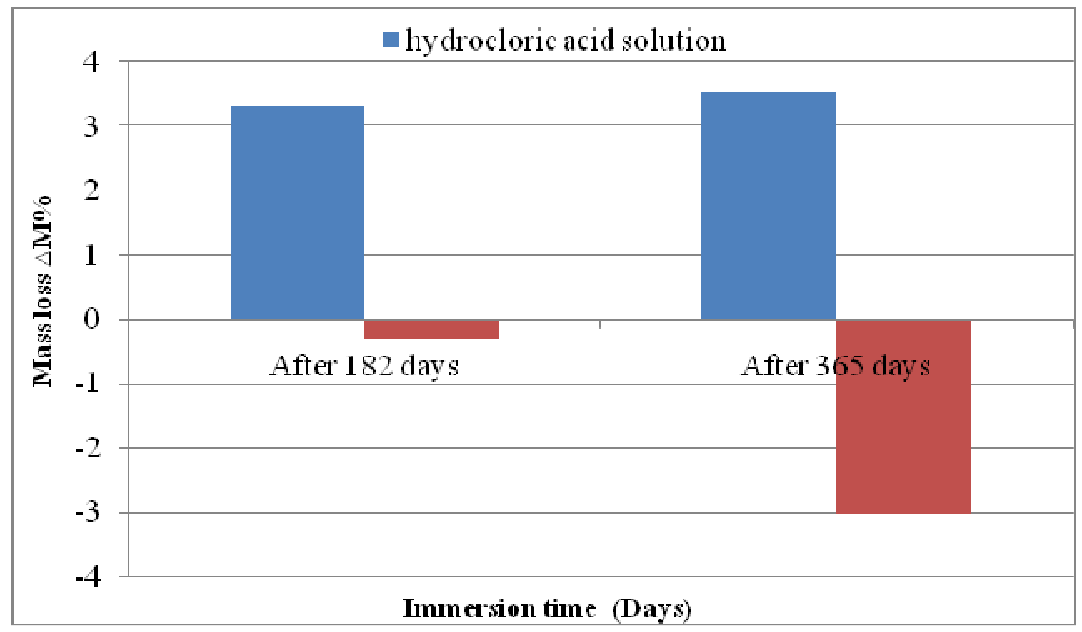

Fig.3.The loss of mass of the UHPFC as a function of the age of immersion in $\mathrm{HCl}$ and $\mathrm{BaSO}_{4}$ 
Durability of ultra-high performance fibered concretes made from local raw materials in two aggressive media of hydrochloric acid and barium sulphates

UHPFCs show mass losses of $3.52 \%$ in hydrochloric acid solution and mass gains of $3.029 \%$ in the brium sulphates respectively after one year of chemical treatment:

- The loss of mass is due to the fact that the cement, after hydration, releases a considerable part of free calcium hydroxide $\left(\mathrm{Ca}(\mathrm{OH})_{2}\right)$ which can be leached out when it is subjected to attack by hydrochloric acid $(\mathrm{HCl})$ by giving calcium hydroxide, according to the following chemical reaction[26]:

$$
\mathrm{Ca}(\mathrm{OH})_{2}+2 \mathrm{HCl} \rightarrow \mathrm{CaCl}_{2}+2 \mathrm{H}_{2} \mathrm{O}
$$

Hydrochloric acid, a strong acid which, by reaction with cement lime, gives rise to calcium chloride, a highly soluble salt that is very aggressive towards Portland cements $[27,28]$.

- The weight gain observed for BFUP immersed in the barium sulphates solution is surely due to the substitution of $\mathrm{Ca}^{2+}$ ions by $\mathrm{Ba}^{2+}$ [29] by giving gypsum, according to the following reaction:

$$
\mathrm{Ca}(\mathrm{OH})_{2}+\mathrm{BaSO}_{4} \rightarrow \mathrm{CaSO}_{4}+\mathrm{Ba}(\mathrm{OH})_{2}
$$

\subsubsection{The density}

The evolution of the density of UHPFC with immersion time is shown in Figure 3, which shows a decrease in acid and an increase in sulphates.

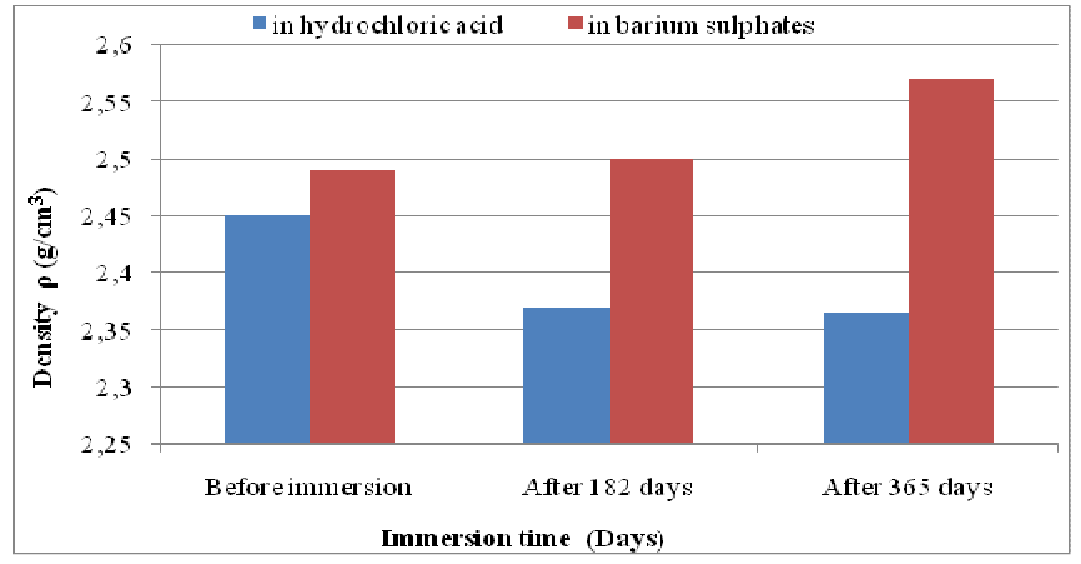

Fig. 4. The density of BFUHPs as a function of the age of immersion in $\mathrm{HCl}$ and $\mathrm{BaSO}_{4}$ 


\subsubsection{The mechanical performance of BFUPs}

In order to evaluate the mechanical performance of the UHPCs left in the air as well as those immersed in the two aggressive solutions for one year, mechanical crushing was performed to measure the mechanical resistance.

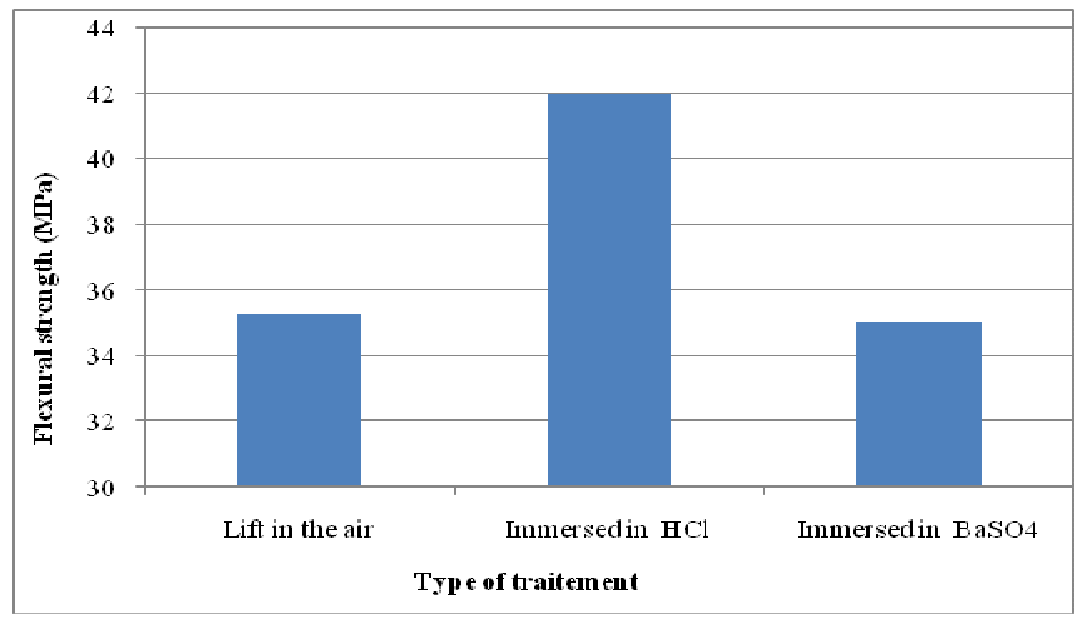

Fig.5. Evolution of flexural strengths with the type of treatment

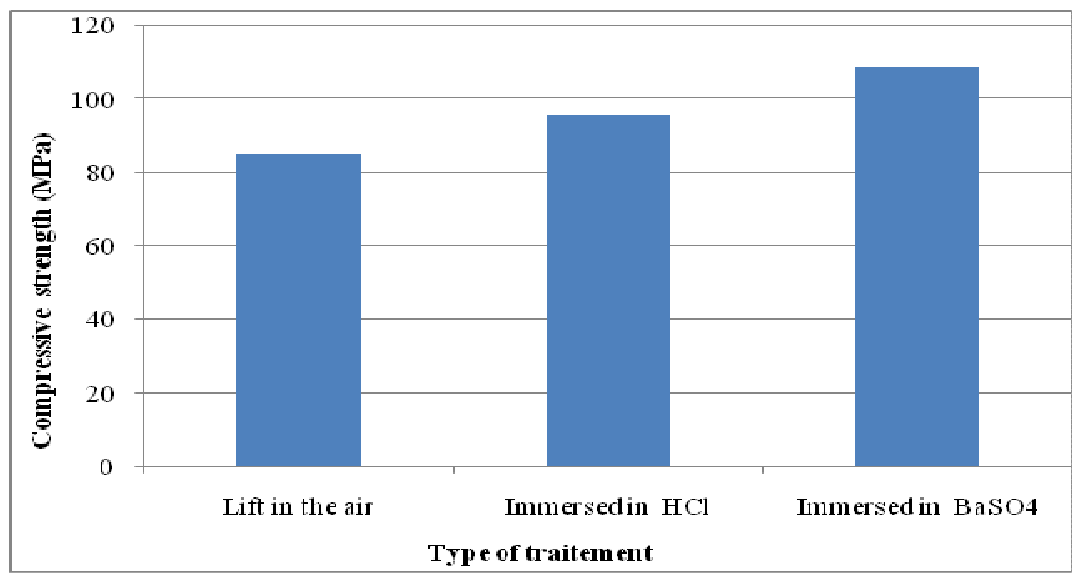

Fig.6. Evolution of compressive strengths with the type of treatment

From the results of the mechanical crashes we can see that:

- The bending tensile strength of UHPFCs immersed in five-fold molar hydrochloric acid solution is better than that of UHPFCs left in the air or immersed in barium sulfate solution for a period of one year. 
Durability of ultra-high performance fibered concretes made from local raw materials in two aggressive media of hydrochloric acid and barium sulphates

- In compression, UHPFCs immersed in $\mathrm{HCl}$ are more resistant than those immersed in $\mathrm{BaSO} 4$ and less resistant when compared to those left in the air.

The results of the macroscopic study, including mass loss, density and mechanical crushing, show that the UHPFC submerged in the two aggressive five-fold molar solutions resist chemical aggression compared to those left in the air for one year.

The introduction of dune sands in the manufacture of high-performance, chemically resistant fibrated concrete is doubly beneficial in terms of strength and economy.

The presentation will be clear and concise, and the symbols used will be defined within a list of symbols (if any). The International System (SI) of units of measurement will be used. For editing use the styles defined in this document, to keep the required format of the text. Predefined styles names start with "RRIC_".

\section{Conclusions}

The use of dune sand in the production of high-performance and resistant fiberreinforced concrete for aggressive environments is beneficial.

In order to better understand the behavior of our UHPFCs regarding the chemical reactions responsible for slowing down degradation in their cementitious matrices in response to chemical attacks, microscopic analysis by X-ray diffraction (XRD) and scanning electron microscopy (SEM)on powders from UHPFC samples is necessary and will be the subject of the next study.

\section{References}

[1] J .Baron, J.P .Ollivier, , La Durabilité des Bétons”, in Presses de l’ENPC, Paris, 1992.

[2] AM. Neville, „Propriétés des bétons”, Traduit par le CRIB, Edition Eyrolles, Paris, 2000.

[3] G .Arliguie, H .Horain, „Grandeurs Du Béton : Grandeurs associées à la durabilité des bétons”, in Presse de l'école nationale des ponts et chaussées, France, 2007.

[4] L .Laoufi, Y.Senhadji, A .Benazzouk, T .Lang, M .Mouli, I .Laoufi, A.S .Benosman, „, Assessment of pozzolanic mortars sustainability exposed to chemical attack", in J. Mater. Environ. Sci, vol. 7, no. 5, 2016, pp.1835-1845.

[5] S .Lasfar, I .Mouallif, A .Latrach, M .Chergui, A .Choukir, A .Diab, „Resistance of two different types of concrete pipes used in sewer systems under sulfuric acid and sodium sulfate", in $\mathbf{J}$. Mater. Environ. Sci, vol. 6, no. 10, 2015, pp. 3002-3014.

[6] AFNOR, NF IN 197-1, „Composition, spécifications et critères de conformité”. Ciment -Partie 1, Février 2001.

[7] AFNOR, NF EN 934-2/A2, ,adjuvants pour béton- Définitions, exigences, conformité, marquage et étiquetage". Adjuvants pour béton, mortier et coulis- Partie 2, Avril 2006.

[8] F .Ait Medjber, M .Saidi, B .Safi, M .Samar, ,Strength improvement of a High Performance Fiber Reinforced Concrete (HPFRC) containing local raw materials", in International Journal of Physical Sciences, vol. 9, no. 18, 2014, pp.402-412. 
Farida Ait Medjber, Mohammed Saidi

[9] NF EN 196-1. P15-471-1, „Méthodes d'essais des ciments”- Partie 1: détermination des résistances", Septembre 2016.

[10] ASTM C348 - 08, Standard Test Method for Flexural Strength of Hydraulic-Cement Mortars, which appears in the Annual Book of ASTM Standards Vol. 4, no. 1.

[11] ASTM C349 - 08, „Standard Test Method for Compressive Strength of Hydraulic-Cement Mortars (Using Portions of Prisms Broken in Flexure), which appears in the Annual Book of ASTM Standards Vol. 4, no.1.

[12] B .Safi, A .Benmounah, M .Saidi, „Rheology and zeta potential of cement pastes containing calcined silt and ground granulated blast-furnace slag", in Materiales de Construcción, vol. 61, no. 303, 2011, pp. 353-370.

[13] L .Struble, G.K .Sun, „Viscosity of Portland cement Paste ace has Function off Concentration. Advanced Cement Based Materials", vol. 2, no. 2, 1995, pp. 62-69.

[14] C.F .Ferraris, „Measurement of the rheological properties of performance high concrete; State of the art carry forward", in Newspaper of Research, the National Institute of Standards and Technology, vol.104, no. 5, 1999, pp.461-478.

[15] F .Ait Medjber, M .Saidi, H .Mechakra, B .Safi, „Assessing the effectiveness of dune sand as a mineral addition to produce ultra-high performance fiber reinforced concrete", in Romanian Journal of Civil Engineering, vol. 10, no. 1, 2019, pp. 34-50.

[16] M .Zeghad, J .Mitterpach, B .Safi, B .Amrane, M .Saidi, „Reuse of refractory brick wastes (RBW) as a Supplementary cementitious material in a concrete". In Periodica Polytechnica Civil Engineering, vol. 61, 2017, pp. 81-87.

[17] R .Yu, P .Tang, P .Spiesz, H.J.H .Brouwers, ,A study of multiple effects of nano-silica and hybrid fibers on the properties of Ultra-High Performance Fiber Reinforced Concrete (UHPFRC) incorporating waste bottom ash (WBA)", in Construction and Building Materials 60, 2014, pp. 98-110

[18] H.S ,Arel, „Effects of curing type, silica fume fineness, and fiber length on the mechanical properties and impact resistance of UHPFRC", in Results in Physics, vol.6, 2016, pp.664-674.

[19] N.H .Yi, J.H.J .Kim, T.S .Han, Y.G .Cho, J.H .Lee, „Blast-resistant characteristics of ultra high strength concrete and reactive powder concrete", in Constr Build Mater, vol. 28, 2012, pp. 694 707.

[20] P .Richard, „Reactive Powder Concrete: A New-Ultra High Strength Cementitious Material”, in Proceedings of the Fourth International Symposium on the Utilization of High-Strength/HighPerformance Concrete, 29-31 May 1996, Paris, France, Ed. F. de Larrard, R. Lacroix, pp. 13431349.

[21] S .Kazemi, A .Lubell, „, Influence of Specimen Size and Fiber Content on Mechanical Properties of Ultra-High-Performance Fiber-Reinforced Concrete", in ACI Materials Journal, vol.109, no. 6, November-December 2012, pp. 675-684.

[22] M. Schmidt, ,Sustainable Building With Ultra-High-Performance Concrete (UHPC) Coordinated Research Program in Germany", Proceedings of Hipermat 3rd International Symposium on UHPC and Nanotechnology for High Performance Construction Materials, Ed., Schmidt, M., Fehling, E., Glotzbach, C., Fröhlich, S., and Piotrowski, S., Kassel University Press, Kassel, Germany, 2012, pp. 17-25.

[23] S .Abbas, A .M .Soliman, M. L .Nehdi, , Exploring mechanical and durability properties of ultra-high performance concrete incorporating various steel fiber lengths and dosages", in Construction and Building Materials vol.75, 2015, pp.429-441.

[24] D. J .Kim, S. H .Park, G .S .Ryu, K. T .Koh, „Comparative flexural behavior of Hybrid Ultra High Performance Fiber Reinforced Concrete with different macro fibers", in Construction and Building Materials vol. 25, 2011, pp.4144-4155.

[25] ASTM C 267-96, "standard test methods for chemical resistance of mortars, grouts, and monolithic surfacing and polymer concretes", Annual Book of ASTM Standards, American Society for Testing and Structures, June 1996. 
Durability of ultra-high performance fibered concretes made from local raw materials in two aggressive media of hydrochloric acid and barium sulphates

[26] L .Laoufi,Y.Senhadji, A .Benazzouk, T .Langlet, M .Mouli, I .Laoufi, A.S .Benosman, „Assessment of pozzolanic mortars sustainability exposed to chemical attack”, in J. Mater. Environ. Sci. vol.7 no.5, 2016, pp.1835-1845.

[27] V .Zivica, A .Bajza, „Acidic attack of cement based materials- a review. Part1: Principle of acidic attack", Construction and Building Materials, vol.15, 2001, pp. 331-340.

[28] V .Zivica, A .Bajza, , Acidic attack of cement based materials- a review. Part2: Facto,,rs of rate of acidic attack and protective measures", in Construction and Building Materials, vol. 16, 2002, pp. 215-222.

[29] Nicolas Bur, ,, Etude des caractéristiques physico-chimiques de nouveaux bétons éco-respectueux pour leur résistance à l'environnement dans le cadre du développement durable", $\mathrm{PhD}$ Thesis, University of Strasbourg, INSA of Strasbourg, 2012. 